\title{
Algılanan Sosyal Destek ile Yaşam Tatmini ve Özgüven İlişkisi: Göçmenler Üzerinde Bir Araştırma
}

\author{
DOI: 10.26466/opus.585405 \\ * \\ İnci Fatma Doğan* \\ * Dr. Öğr. Üyesi, Kahramanmaraş Sütçü İmam Üniversitesi, Türkoğlu MYO, Yönetim ve \\ Organizasyon Bölümü, Türkoğlu / Kahramanmaraş / Türkiye \\ E-Posta: ikurtulgan@gmail.com \\ ORCID: $0000-0002-9749-2878$
}

Öz

Göç hareketleri, göç sürecine katılan ve yaşadıkları yerleri terk etmek durumunda kalanların yaşamlarında önemli ekonomik, sosyal, psikolojik değişimlerin yaşanmasına neden olmaktadır. Göçe katılan bireyler karşılaşıkları değişimler karşısında kendilerini yalnız, dışlanmış hissedebilmekte ve yaşamdan tatmin olamayan mutsuz bireylere dönüşebilmektedir. Ailelerinden, arkadaşlarından veya tanıdık diğer insanlardan aldikları sosyal destek sayesinde ise göç ettikleri topluma uyum sağlayıp o toplumla bütünleşmeleri mümkün olabilmektedir. Bu çalışmadaki temel amaç, ülkemize göç etmek durumunda kalan bireylerin alğladıkları sosyal desteğin onlarn yaşam tatmin ve özgüven düzeylerini etkileyip etkilemediğini ortaya koymak suretiyle bu kavramlar arasındaki ilişkiyi incelemektir. Bu amaçla bir alan çalışması kapsamında Kahramanmaraş ilinde bulunan, ülkelerindeki sorun nedeniyle Türkiye'ye göç etmiş bireylerin sosyal destek algılarının yaşam tatminleri ve özgüven düzeyleri üzerindeki etkisi araştırlmak istenmiştir. Araştırmada veri toplama aracı olarak anket yöntemi tercih edilmiştir. Anket sonucu elde edilen veriler SPSS programı aracilığılyla frekans, korelasyon ve regresyon analizlerine tabi tutulmuştur. Araştırma sonucuna göre algilanan sosyal destek düzeyinin artmasının bireylerin yaşam tatminlerinin ve özgüven düzeylerinin de pozitif yönde artmasına neden olduğunu ortaya koymaktadır.

Anahtar Kelimeler: Sosyal Destek, Yaşam Tatmini, Özgüven 


\title{
The Relationship Between Perceived Social Support, Life Satisfaction and Self-Confidence: A Research on Immigrants
}

\begin{abstract}
Migration movements cause important economic, social and psychological changes in the lives of those who participate in the migration process and who have to leave their places of residence. Individuals participating in migration may feel lonely, excluded in the face of changes and become unhappy individuals who are not satisfied with life. With the social support they receive from their families, friends or other familiar people, it is possible for them to adapt and integrate with the society they migrated. The main purpose of this study is to examine the relationship between perceived social support, life satisfaction and self-reliance by revealing whether social support perceived by individuals who have to migrate to our country affect their life satisfaction and self-confidence levels. For this purpose, it is aimed to investigate the effects of the social support perceptions on the life satisfaction and self-confidence of the individuals in Kahramanmarass province that migrated to Turkey due to the problems in their countries. The survey method was preferred as data collection tool. The data obtained from the survey were subjected to frequency, correlation and regression analysis via SPSS program. According to the results of the research, it is revealed that the increase in perceived social support causes the life satisfaction and self-confidence levels of the individuals to increase positively.
\end{abstract}

Keywords: Social Support, Life Satisfaction, Self-Confidence 


\section{Giriş}

Nedenleri ve sonuçları açısından çok boyutlu olarak ele alınması gereken göç olgusu, önüne geçilemez sosyal bir sorunu teşkil etmektedir (Koçak ve Gündüz, 2016, s.67). Daha yüksek gelir düzeyi, daha iyi yaşam koşulları, daha iyi eğitim alma imkânı, daha güvenli bir ortam gibi ekonomik, sosyal, kültürel, siyasi çeşitli faktörler göç hareketlerine ve bu göçün sürekli bir biçimde devam etmesine neden olmaktadır (Akhan ve Batmaz, 2015, s.24). İnsanları çeşitli nedenlerle yaşadıkları yerleri terk etmek zorunda bırakan göçler sonucunda göçmenlerin yeni yerleşim yerlerine uyum sağlamaları oldukça sıkıntılı, zor bir süreçtir. İnsanların doğup büyüdükleri yerlerden koparak kendilerini ait hissetmedikleri farklı bir ülkeye yerleşmeleri insanlarda yalnızlık, dışlanmışlık, tükenmişlik gibi duygulara neden olabilmekte ve yaşam tatminlerini azaltabilmektedir (Ad1güzel, 2016, s.173). Biyolojik ve psikolojik ihtiyaçları kadar göç eden insanları karşılayan yeni hayat, yeni koşullar, dış talepler ve baskılar onların uyum süreçlerini zorlaştırmaktadır (Silverman, 1987). İnsanlar yaşadıkları değişimlere uyum sağlamada ve karşılaştıkları zorluklarla başa çıkmada kendilerinde yeterli gücü bulamazlarsa bu durum onlarda çeşitli fiziksel, psikolojik ve davranışsal sonuçlara yol açabilmektedir (Lahey, 2004; Agoha vd., 2015, s.27-28). Ne var ki ailesinden, akrabalarından, arkadaşlarından veya çevrelerindeki diğer insanlardan sosyal destek alan insanların yaşadıkları sıkıntılı süreci daha kolay bir şekilde atlatabilecekleri ifade edilmektedir (Gün ve Bayraktar, 2008, s. 168). Göç ettikleri toplum tarafından benimsenme, iş bulup ekonomik anlamda güvende olabilme, ihtiyaçlarını giderebilme, çevrelerindeki insanlarla iyi düzeyde, tatmin edici sosyal ilişkiler kurabilmede göçmenlerin alacakları sosyal desteğin önemli bir rol oynadığı düşünülmektedir. Göçmenlerin algıladıkları sosyal destek sonucunda da fiziksel ve psikolojik olarak kendilerini iyi hissetmeleri, yaşam tatmin düzeylerinin artması ve özgüvenlerinin yükselmesi beklenmektedir.

Literatürde, bireylerin yaşam tatminleri ile yaşam tatmin düzeyleri üzerinde önemli etkiye sahip faktörlerden biri olarak ele alınan sosyal destek arasındaki ilişkiyi inceleyen çalışmalar mevcuttur (Akın, 2008; Boylu ve Günay, 2018; Hamaideh vd., 2014; Kasprzak, 2010; Özdevecioğlu, 2004; 
Polatc1, 2015; Tamannaeifar ve Behzadmoghaddam, 2016; Topkaya ve Kavas, 2015; Zhou ve Lin, 2016). Mcknight vd. (2002, s.679) de sosyal desteğin ergenlerin yaşam tatmininin en güçlü yordayıcılarından biri olduğunu ifade etmişlerdir. Yine sosyal desteğin bireylerin özgüvenleri üzerinde de olumlu etkilerinin olduğu bilinmektedir (Rees ve Freeman, 2007; Süpçeler, 2016). Ancak yapılan literatür taraması sonucunda sosyal destek ile yaşam tatmini veya sosyal destek ile özgüven arasındaki ilişkiyi göçmenler üzerinde araştıran herhangi bir çalışmaya rastlanılmamıştır. Göçmenlerle ilgili yapılan çalışmalar incelendiğinde sosyal destek konusunun ayrı (Çetin ve Uysal, 2013; Yaşar vd., 2014), yaşam tatmini konusunun ayrı (Akhan ve Batmaz, 2015; Calvo vd., 2017; Gunasekara vd., 2014; Kim, 2000; Şeker ve Sirkeci, 2014; Vohra ve Adair, 2000) ele alındığı dikkat çekmiştir. Bu kapsamda bu çalışmada göçmenlerin algıladıkları sosyal desteğin yaşam tatmini ve özgüven düzeyleri üzerinde etkisinin olup olmadığı incelenmek istenmiştir.

\section{Algilanan Sosyal Destek}

Sosyal destek konusunda çalışmış Pearson (1990)'ın belirttiği üzere sosyal destek kavramı, yeni bir kavram olmayıp bilim ve sanat alanında farklı isimler altında da olsa incelenmiş, sosyal, davranışsal ve sağlık bilimleriyle ilgili literatürde ele alınmış bir kavramdır (Yıldırım, 1997, s.81).

Sosyal birer varlık olan insanlar bedensel, duygusal, sosyal, çevresel çeşitli değişimler yaşadıkları dönemlerde anne veya babalarının, arkadaşlarının, akrabalarının desteğine ihtiyaç duyarlar (Çavuş ve Pekkan, 2017, s.520). Sosyal destek algısı insanların yeni girdikleri ortamlara alışmasında, kolay uyum sağlamalarında, kendilerine olan güveni geliştirmelerinde hayati önem taşımaktadır (Polatçı, 2015, s.28). Genel olarak sosyal destek algısı, bir kişinin aile, arkadaş gibi önemli sosyal ağ üyeleri tarafından desteklendiğinin bilişsel olarak değerlendirilmesidir (Toepfer, 2010, s.57). Zor zamanlarında veya mutlu günlerinde her daim ailesini, arkadaşlarını, meslektaşlarını yanında hissetmesidir, onlar tarafından kabul görmesidir (Özdevecioğlu, 2004, s.215). Sosyal destek rolleri, araçsal (maddi yardımlar ve hizmetler), duygusal (empati, sevgi, güven ve bakım), bilgilendirme (tavsiye ve öneri) veya değerlendirme (onaylama ve geri bildi- 
rim) desteği şeklinde olabilir (House, 1981; Agoha vd., 2015, s.28). Bir bireyin sosyal destek kaynaklarını, ailesi, arkadaşları ve bireyler için önemli sayılan akrabaları, komşuları, meslektaşları ya da etkileşimde bulunduğu diğer özel insanlar oluşturmaktadır (Zimet vd., 1988, s. 32).

İnsanlar sosyal destek alsalar dahi bunu hissetmeyebilirler. Bu yüzden dışarıdan destek alınması kadar bu desteğin, destek alan insanlar tarafından algılanması da oldukça önem taşımaktadır (Süpçeler, 2016, s. 10). Bireylerin algıladıkları sosyal destek ve sosyal destek sonuçlarına dair inançları bu algılanan sosyal destekten elde edecekleri faydalar konusunda oldukça etkili olmaktadır (Agoha vd., 2015, s.28).

\section{Yaşam Tatmini}

Yaşam tatmini, bireylerin kişisel, psikolojik, davranışsal, sosyal, kişilerarası ilişkilerinin olumlu yansıması olup ruh sağllğının kilit bir göstergesidir (Proctor vd., 2017, s.1). Bireylerin kendi koşullarını, olması gerektiğini düşündükleri uygun standartlarla karşılaştırmaları durumudur (Diener vd., 1985, s.71). Bireylerin kendi yaşamlarının tümüne ilişkin bilişsel değerlendirmeleridir (Diener, 1994; Mcknight vd. 2002, s.677). Bireylerin iç huzura erişmesinde tatmin önemli bir rol oynamaktadır (Batista, 2018, s.37).

Bireylerin yaşam tatminlerini etkileyen unsurların ilgili literatürde, kişisel, işle ilgili, çevresel ve toplumsal olmak üzere dört temel faktörden oluştuğu ifade edilmektedir (Diener, 1984; Farrell ve Rusbult, 1981; Akt.Özdevecioğlu, 2003, s.697). Kapteyn vd. (2009) tarafından gerçekleştirilen bir çalışmada da yaşam tatmininin iş veya günlük aktiviteler, aile ve sosyal ilişkiler, sağlık ve gelir düzeyi olmak üzere dört faktör tarafından sağlandığı sonucuna ulaşılmıştır.

\section{Özgüven}

Özgüven, bireylerin kendileri ile ilgili yapmış olduğu yorumların değerlendirmeleri sonucunda oluşan, davranışlarını etkileyen, kendilerini değerli, önemli, başarılı bulup bulmamaya yönelik inançlarını, tutumlarını ifade eder (Coopersmith, 1967; Özdemir, 2016, s.137). Bir bireyin kendi 
olumlu veya olumsuz yönlerinin farkında olduğu öznel bir durumdur. İnsanların durup sizi fark etmelerine, size saygı duymalarına ve potansiyel bir sırdaş, arkadaş veya rakip olabileceğinizi tahmin etmelerine neden olan bir olgudur (Gandhi, 2010, s.8). Bireylerin kendilerini değerlendirmeleri sonucunda ortaya çlkan memnuniyet veya memnuniyetsizlik duygusu ile ilişkilidir (Thomas ve Raj, 1985, s.21). Özgüven gelişimi önce ailede başlayıp sonrasında arkadaşlar, öğretmenler ve çevrenin etkisi ile şekillenmektedir (Süpçeler, 2016, s.2).

\section{Araştırma Yöntemi}

$\mathrm{Bu}$ çalışma kapsamında ülkelerindeki çeşitli sorunlar nedeniyle Türkiye'ye göç etmiş ve Kahramanmaraş iline yerleşerek burada bulunan bireylerin sosyal destek algılarının yaşam tatminleri ve özgüven düzeyleri üzerindeki etkisi araştırılmak istenmiştir. Ekonomik, siyasal, sosyo-kültürel çeşitli unsurlar sebebiyle vatanlarından göç etmek durumunda kalan bireylerin gittikleri yerlere uyum sağlamaları oldukça sıkıntılı bir süreçtir. Bu bireylerin yaşadıkları sıkıntıların yaşam tatminlerini ve özgüvenlerini etkileyeceği düşünülmektedir. Bu amaçla Kahramanmaraş'ta yaşayan ve bir kamu kuruluşunda eğitim alan göçmenler arasından basit tesadüfi örnekleme yöntemi ile seçilen 116 göçmen ile bir anket uygulaması gerçekleştirilmiş olup ülkemize göç eden bireylerin sosyal destek algılarının yaşam tatminlerini ve özgüven düzeylerini etkileyip etkilemediği araştırılmiştır.

Anket formunda yer alan açık ve kapalı uçlu sorular ile Likert tarzı önermeler ilgili literatürden türetilmiştir. Ankette yer alan algilanan sosyal destek kavramını ölçmeye yönelik Zimet vd. (1988)'nin geliştirdiği 12 soru ve 3 alt boyuttan oluşan ölçek kullanılmıştır ve ölçekte yer alan ifadeler önce Türkçeye çevrilmiş ardından alanında uzman akademisyenler tarafından kontrol edilmiştir. Yaşam tatminini ölçmeye yönelik Diener vd. (1985) tarafından geliştirilen 5 sorulu ölçek kullanılmıştır. Ancak yaşam tatminini ölçen bir soru güvenilirliği düşürmesi nedeniyle analiz kapsamı dışında tutulmuştur. Özgüveni ölçmeye yönelik ise Akın (2007) tarafından geliştirilen 33 sorulu ölçek kullanılmıştır. Ölçeklerde beşli likert ölçeğinden yararlanılmış ve "1:Kesinlikle katılmıorum, 2:Katılmıyorum, 
3:Kararsızım, 4:Katılıyorum ve 5:Kesinlikle katılıyorum" şeklinde derecelendirilme yapılmıştır.

Araştırma kapsamında elde edilen veriler SPSS programı ile analize tabi tutulmuştur. Kolmogorov-Smirnov testi ile verilerin normal dağıllım gösterip göstermediği tespit edilmiştir. Bu test sonucunda verilerin normal dağılım gösterdiği görülmüş olup parametrik analiz yöntemler tercih edilmiştir. Araştırma kapsamında hipotezlerin analizi için frekans, korelasyon ve regresyon analizlerinden faydalanılmıştır.

\section{Araştırma Modeli}

Bu çalışmada algilanan sosyal desteğin göçmenlerin yaşam tatminleri ve özgüven düzeyleri üzerindeki etkisi araştırılmış olup

- “H1: Sosyal destek algısı göçmenlerin yaşam tatminini pozitif ve anlamlı olarak etkiler." ana hipotezi çerçevesinde;

- "H1a: Aile sosyal destek algısı göçmenlerin yaşam tatminini pozitif ve anlamlı olarak etkiler."

- "H1b: Özel kişi sosyal destek algısı göçmenlerin yaşam tatminini pozitif ve anlamlı olarak etkiler."

- "H1c: Arkadaş sosyal destek algısı göçmenlerin yaşam tatminini pozitif ve anlamlı olarak etkiler."

- "H2: Sosyal destek algısı göçmenlerin özgüvenini pozitif ve anlamlı olarak etkiler." ana hipotezi çerçevesinde;

- "H2a: Aile sosyal destek algısı göçmenlerin özgüven düzeyini pozitif ve anlamlı olarak etkiler."

- "H2b: Özel kişi sosyal destek algısı göçmenlerin özgüven düzeyini pozitif ve anlamlı olarak etkiler."

- "H2c: Arkadaş sosyal destek algısı göçmenlerin özgüven düzeyini pozitif ve anlamlı olarak etkiler."

hipotezleri geliştirilmiştir ve bu hipotezler doğrultusunda araştırmanın modeli oluşturulmuş olup şekil 1'de gösterilmektedir. 


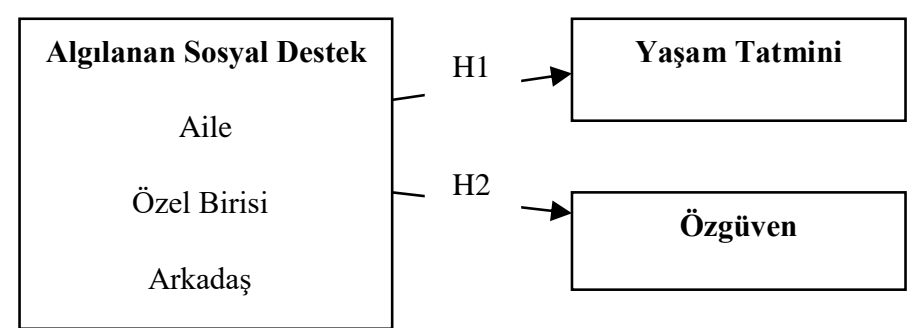

Şekil 1. Araştırma Modeli

Bu model kapsamında algılanan sosyal desteğin ve boyutlarının yaşam tatmini ve özgüven düzeyi üzerindeki etkisi araştırılmıştır.

\section{Araştırma Bulguları}

Araştırmada yer alan değişkenlerin güvenirliliği, yaygın olarak kullanılan Cronbach Alfa değerleri ile ölçümlenmiştir. Tablo 1'de yer alan bu sonuçlar için algılanan sosyal destek ve alt boyutu olan özel birisi ile özgüven değişkenlerinin değeri 0,81 ve üzerinde bulunmuş olup bu değerler Özdamar (1999)'ın yüksek güvenilir düzey olarak tanımladığı aralıkta yer almaktadır. Diğer değişkenlerin tamamının değeri ise 0,61 ve üzerinde bir değerde olup orta güvenilir düzey değer aralığındadırlar (Yaşar, 2014, s. 63).

Tablo 1.Araştırma Değişkenlerinin Güvenilirliği

\begin{tabular}{llc}
\hline Değişkenler & Cronbach Alfa Değeri & $\begin{array}{l}\text { Önerme } \\
\text { Sayıları }\end{array}$ \\
\hline Algılanan Sosyal Destek &, $\mathbf{9 0 6}$ & $\mathbf{1 2}$ \\
\hline Aile &, 793 & 4 \\
\hline Özel Bir İnsan &, 829 & 4 \\
\hline Arkadaş &, 803 & 4 \\
\hline Yaşam Tatmini &, $\mathbf{6 0 7}$ & $\mathbf{4}$ \\
\hline Özgüven &, 876 & 33 \\
\hline
\end{tabular}

Katılımcılara ait demografik özellikler Tablo 2'de sunulmuştur. 
Tablo 2. Araştırmaya Katılanların Demografik Özellikleri

\begin{tabular}{|c|c|c|c|c|c|}
\hline & $\mathbf{N}$ & $\%$ & & $\mathbf{N}$ & $\%$ \\
\hline Cinsiyet & & & MedeniDur. & & \\
\hline Kadın & 56 & 48,7 & Bekar & 60 & 44,2 \\
\hline Erkek & 59 & 51,3 & Evli & 50 & 53,1 \\
\hline Yaş & & & Eğitim Dur. & & \\
\hline 20 yaş ve altı & 37 & 32,7 & İlkokul & 6 & 5,4 \\
\hline $21-30$ & 44 & 38,9 & Ortaokul & 12 & 10,8 \\
\hline $31-40$ & 17 & 15,0 & Lise & 52 & 46,8 \\
\hline $41-50$ & 10 & 8,8 & $\mathrm{MYO}$ & 7 & 6,3 \\
\hline 51 yaş ve üstü & 5 & 4,4 & Üniversite & 32 & 28,8 \\
\hline Gelir Düzeyi & & & Çalış.Süresi & & \\
\hline 500 TL ve altı & 1 & 0,9 & 1 aydan az & 6 & 17,6 \\
\hline $501-750 \mathrm{TL}$ & 2 & 1,8 & $1-3$ ay & 6 & 17,6 \\
\hline 751-1000 TL & 6 & 5,2 & 4-6 ay & 7 & 20,6 \\
\hline $1001-1250 \mathrm{TL}$ & 7 & 6,1 & 7 ay- 1 yil & 5 & 14,7 \\
\hline \multirow[t]{2}{*}{1250 TL ve üstü } & 6 & 5,2 & $2-3$ yil & 6 & 17,6 \\
\hline & & & 4 yıl ve üstü & 4 & 11,7 \\
\hline Göç Durumu & & & Çalışma Durumu & & \\
\hline Ailesi göç etmiş & 74 & 65,5 & Çalışan & 35 & 30,7 \\
\hline Kendisi göç etmiş & 36 & 31,9 & Çalışmayan & 77 & 67,5 \\
\hline
\end{tabular}

Araştırma kapsamında anketi yanıtlayan çalışanların \%48,7'si kadın, $\% 51,3$ 'ü erkeklerden oluşmaktadır. Katılımcıların \% 44,2'si bekar, \% 53.1'i evlidir. Katılımcıların yaşları dikkate alındığında \%32,7'sinin 20 yaşın altında olduğu ve \%38,9'unun 21-30 yaş aralığında, \%15'inin 31-40 yaş aralığında, \%8,8'inin 41-50 yaş aralığında yer aldığı ve sadece \%4,4'ünün 51 yaş üzerinde olduğu görülmüştür. Bu durum çeşitli nedenlerle ülkemize göç etmek durumunda kalan bireylerin oldukça genç yaşta olduklarına işaret etmektedir. Katılımcıların neredeyse yarıya yakınının $(\% 46,8)$ lise, $\% 28,8^{\prime}$ inin de üniversite mezunu olduğu dikkat çekmiştir. Katılımcıların gelir düzeyleri dikkate alındığında asgari geçim düzeyinin altında bir gelir düzeyine sahip oldukları dikkat çekmektedir. 35 (\%30,7) katılımcının bir işte çalıştığı, 77 katılımcının $(\% 67,5)$ ise çalışmadığ tespit edilmiştir. Çalışan kesime bakıldığında da genel anlamda katılımcıların yaptıkları işlerde uzun süreli çalışmadıkları görülmektedir.

Araştırmadaki hipotezleri test etmeden önce modelde yer alan değişkenlerin istatistiksel açıdan birbirleri ile ilişkilerinin derecesine bakılmıştır. 
Tablo 3 ve Tablo 4'de değişkenlere ait aritmetik ortalama, standart sapma değerleri ve korelasyon analizi sonuçları gösterilmiştir.

Tablo 3. Araştırma Değişkenlerine Ait Ortalama ve Standart Sapma Değerleri

\begin{tabular}{lll}
\hline Değişkenler & Ort. & s.s. \\
\hline 1.Alg1lanan Sosyal Destek & 3,879 &, 830 \\
\hline Aile & 4,012 &, 880 \\
Özel Bir İnsan & 3,966 &, 915 \\
Arkadaş & 3,656 &, 973 \\
\hline 2.YaşamTatmini & 2,517 &, 927 \\
\hline 3.Özgüven & 3,536 &, 532 \\
\hline
\end{tabular}

Tablo 3'deki sonuçlar incelendiğinde en yüksek ortalamaya sahip değişkenin algilanan sosyal destek alt boyutu olan aile değişkeni olduğu görülmektedir. Dolayısıyla katılımcıların aile sosyal destek algısını ölçmeye yönelik sorulara "katılıyorum" seçeneği yönünde cevaplar verdikleri anlaşılmaktadır. Yani çalışanlar ailelerinden sosyal destek aldıklarını ifade etmişlerdir. En düşük ortalamaya sahip değişken ise yaşam tatminidir. Katılımcıların diğer değişkenlere oranla yaşam tatmini önermelerine "katılmıyorum" seçeneğine yakın cevaplar verdikleri anlaşılmaktadır. Bu durumda ülkemize göç etmiş bireylerin yaşamlarından memnuniyet duymadıkları ifade edilebilir.

Tablo 4. Araştırma Değişkenlerinin Korelasyon Değerleri

\begin{tabular}{lcccccc}
\hline \multicolumn{1}{c}{ Değişkenler } & $\mathbf{1}$ & $\mathbf{2}$ & $\mathbf{3}$ & $\mathbf{4}$ & $\mathbf{5}$ & $\mathbf{6}$ \\
\hline 1.ASD & 1 & & & & & \\
\hline 2.Aile &, $919^{* *}$ & 1 & & & & \\
\hline 3.Özel &, $914^{* *}$ &, $819^{* *}$ & 1 & & & \\
\hline 4.Ark. &, $867^{* *}$ &, $676^{* *}$ &, $653^{* *}$ & 1 & & \\
\hline 5.YT &, $454^{* *}$ &, $386^{* *}$ &, $422^{* *}$ &, $415^{* *}$ & 1 & \\
\hline 6.Özg &, $690^{* *}$ &, $652^{* *}$ &, $656^{* *}$ &, $553^{* *}$ &, $364^{* *}$ & 1 \\
\hline ** Korelasyon 0.01 düzeyinde anlamlidır. & &
\end{tabular}


Tablo 4'de yer alan korelasyon analizi sonucuna göre göçmenlerin algıladıkları sosyal destek ile yaşam tatmini ve özgüven arasında istatistiksel olarak p $<.01$ düzeyinde anlamlı ilişkiler olduğu tespit edilmiştir. Algılanan sosyal destek ile özgüven arasındaki ilişkinin $(r=, 690)$ algilanan sosyal destek ile yaşam tatmini arasındaki ilişkiye $(\mathrm{r}=, 454)$ oranla daha güçlü olduğu bulunmuştur. Elde edilen bu sonuçlar çalışmada geliştirilen hipotezleri desteklemektedir.

Çalışmanın amaçları doğrultusunda yapılan regresyon analizi sonuçları aşağıdaki tablolarda sunulmaktadır.

Tablo 5. Algılanan Sosyal Desteğin Yaşam Tatmini Üzerindeki Etkisine Yönelik Regresyon Analizi

\begin{tabular}{lccc}
\hline Değişkenler & Beta & $\mathbf{t}$ değeri & p değeri \\
\hline Yaşam Tatmini &, 454 & 5,375 &, 000 \\
& $\Delta \mathbf{R}^{\mathbf{2}=, \mathbf{1 9 9}}$ & $\mathbf{F}=\mathbf{2 8 , 8 8 5}$ &, $\mathbf{0 0 0}$ \\
\hline
\end{tabular}

Çalışmada geliştirilen "H1: Sosyal destek algısı göçmenlerin yaşam tatminini pozitif ve anlamlı olarak etkiler" hipotezini test etmek için yapılan regresyon analizi sonucunda algılanan sosyal desteğin yaşam tatminini yaklaşık \%20 oranında $\mathrm{p}<0,05$ düzeyinde anlamlı ve pozitif yönde etkilediği sonucuna ulaşılmıştır. Dolayısıyla H1 hipotezi kabul edilmiştir.

Tablo 6. Algılanan Sosyal Destek Boyutlarının Yaşam Tatmini Üzerindeki Etkisine Yönelik Regresyon Analizi

\begin{tabular}{lccl}
\hline Değişkenler & Beta & $\mathbf{t}$ değeri & p değeri \\
\hline Aile-Yaş.Tat. &, 386 & 4,403 &, 000 \\
& $\Delta \mathbf{R}^{\mathbf{2}=, \mathbf{1 4 1}}$ & $\mathbf{F}=\mathbf{1 9 , 3 8 6}$ &, $\mathbf{0 0 0}$ \\
\hline Özel Bir &, 422 & 4,901 &, 000 \\
İnsan-Yaş.Tat. & $\Delta \mathbf{R}^{\mathbf{2}=, \mathbf{1 7 0}}$ & $\mathbf{F}=\mathbf{2 4 , 0 2 1}$ &, $\mathbf{0 0 0}$ \\
\hline Arkadaş- Yaş.Tat. &, 415 & 4,807 &, 000 \\
& $\Delta \mathbf{R}^{\mathbf{2}}=\mathbf{, 1 6 5}$ & $\mathbf{F}=\mathbf{2 3 , 1 0 7}$ & $\mathbf{0 0 0}$ \\
\hline
\end{tabular}

Bu çalışmada geliştirilen "H1a: Aile sosyal destek algısı göçmenlerin yaşam tatminini pozitif ve anlamlı olarak etkiler", "H1b: Özel kişi sosyal destek algısı göçmenlerin yaşam tatminini pozitif ve anlamlı olarak etkiler" ve "H1c: Arkadaş sosyal destek algısı göçmenlerin yaşam tatminini pozitif ve anlamlı olarak etkiler" hipotezlerini test etmek üzere yapılan 
regresyon analizi sonuçları tüm geliştirilen hipotezler için istatistiksel olarak anlamlı bulunmuştur. Yani araştırmadaki tüm hipotezler kabul edilmektedir.

Algılanan sosyal desteğin aile boyutunun bağımlı değişkenlerden yaşam tatmin düzeyini \%17 oraniyla diğer değişkenlere oranla daha iyi aç1kladığ1 görülmüştür. Yani göçmenlerin yaşam tatmin düzeylerinde \%17 oranında özel bir kişinin sağladığı sosyal desteğin payı bulunmaktadır. Ayrıca göçmenlerin yaşamdan memnuniyet duymalarında arkadaşlarından gördükleri desteğin \%16,5; ailelerinden gördükleri desteğin de \%14,1 oranında etkisinin olduğu bulgusuna ulaşılmıştır. Bu sonuç, aile ve arkadaşlar tarafından bireylere verilen sosyal desteğin onların sosyal ve psikolojik sorunlarının çözümlenmesinde, karşılaştıkları zorlukları aşmalarında ve özgüven kazanabilmelerinde ve yaşam tatminlerini artırmalarında güçlü bir kaynak olduğunu ifade eden Cutrona vd. (1994, s.369)'nin çalışmasını desteklemektedir.

Tablo 7. Algılanan Sosyal Desteğin Özgüven Üzerindeki Etkisine Yönelik Regresyon Analizi

\begin{tabular}{lccc}
\hline Değişkenler & Beta & $\mathbf{t}$ değeri & p değeri \\
\hline Özgüven &, 690 & 10,041 &, 000 \\
& $\Delta \mathbf{R}^{\mathbf{2}=, \mathbf{4 7 1}}$ & $\mathbf{F}=\mathbf{1 0 0 , 8 1 3}$ &, $\mathbf{0 0 0}$ \\
\hline
\end{tabular}

Çalışmada geliştirilen “H2: Sosyal destek algısı göçmenlerin özgüvenini pozitif ve anlamlı olarak etkiler" hipotezini test etmek amaciyla yapılan analiz sonucuna göre; algılanan sosyal desteğin özgüveni \%47,1 oranında $\mathrm{p}<0,05$ düzeyinde anlamlı, pozitif yönde etkilediği anlaşılmaktadır. Bu veriden hareketle $\mathrm{H} 2$ hipotezi kabul edilmiştir. Dolayısıyla aile, arkadaş veya yakın bir kişiden görülen sosyal desteğin bireylerin özgüven gelişimlerini kolaylaştırdığ ${ }_{1}$ ifade edilebilir. Elde edilen bu sonuç Ainsworth (1982)'ün çalışmasını destekler yöndedir. 
Tablo 8. Algılanan Sosyal Destek Boyutlarını Özgüven Üzerindeki Etkisine Yönelik Regresyon Analizi

\begin{tabular}{lccc}
\hline Değişkenler & Beta & $\mathbf{t}$ değeri & p değeri \\
\hline Aile-Özg. &, 652 & 9,070 &, 000 \\
& $\Delta \mathbf{R}^{2}=, \mathbf{4 2 0}$ & $\mathbf{F}=\mathbf{8 2 , 2 5 9}$ &, $\mathbf{0 0 0}$ \\
\hline Özel Bir İnsan-Özg. &, 656 & 9,169 &, 000 \\
& $\Delta \mathbf{R}^{2}=, \mathbf{4 2 6}$ & $\mathbf{F}=\mathbf{8 4 , 0 6 9}$ &, $\mathbf{0 0 0}$ \\
\hline Arkadaş- Özg. &, 553 & 6,988 &, 000 \\
& $\Delta \mathbf{R}^{2}=, \mathbf{2 9 9}$ & $\mathbf{F}=\mathbf{4 8 , 8 2 9}$ &, $\mathbf{0 0 0}$ \\
\hline
\end{tabular}

Bu çalışmada geliştirilen "H2a: Aile sosyal destek algısı göçmenlerin özgüven düzeyini pozitif ve anlamlı olarak etkiler”, “H2b: Özel kişi sosyal destek algısı göçmenlerin özgüven düzeyini pozitif ve anlamlı olarak etkiler" ve "H2c: Arkadaş sosyal destek algısı göçmenlerin özgüven düzeyini pozitif ve anlamlı olarak etkiler" hipotezlerini test etmek için yapılan regresyon analizi sonucunda tüm hipotezler istatistiksel olarak $\mathrm{p}<0,05$ düzeyinde anlamlı çıkmıştır ve $\mathrm{H} 2 \mathrm{a}, \mathrm{H} 2 \mathrm{~b}$ ve $\mathrm{H} 2$ c hipotezleri kabul edilmiştir.

Göçmenlerin özgüven düzeyi üzerinde özel bir kişinin sağladığı desteğin $(\% 42,6)$ diğer değişkenlere oranla etkisinin daha güçlü olduğu belirlenmiştir. Göçmenlerin arkadaşlarından gördükleri desteğin ise özgüvenleri üzerinde yaklaşık \%30 oranında etkisinin olduğu ve aile ile özel bir kişi tarafından sağlanan desteğe göre daha zayıf kaldığı bulgusuna ulaşılmiştır.

\section{Sonuç}

Algılanan sosyal destek ve boyutlarının katılımcıların yaşam tatmini ve özgüven düzeyleri üzerindeki etkisini araştıran bu çalışmada aile, özel birisi veya arkadaşlardan sağlanan sosyal desteğin katılımcıların yaşam tatminini ve de özgüvenlerini olumlu yönde etkilediği bulgusu elde edilmiştir. Katılımcıların sosyal destek algıları arttıkça yaşam tatminleri ve özgüvenleri de artmaktadir.

Değişkenler arasındaki ilişkiler incelendiğinde; katılımcıların sosyal destek algıları ile yaşam tatminleri ve özgüven düzeyleri arasında istatistiksel olarak anlamlı ilişkilerin olduğu belirlenmiştir. Özellikle algılanan sosyal destek ile özgüven arasındaki ilişkinin yaşam tatmini değişkenine 
göre daha yüksek düzeyde olduğu bulgusuna erişilmiştir. Algılanan sosyal destek boyutları açısından ele alındığında ise özel birinden görülen destek ile özgüven arasındaki ilişkinin diğer değişkenlere göre daha güçlü olduğu dikkat çekmiştir. Yani katılımcıların ihtiyaç duydukları anlarda yanlarında özel biri olduğunda, onları gerçekten rahatlatan özel birilerinin varlığını hissettiklerinde özgüven düzeylerinin bu durumdan olumlu yönde etkilendiği görülmektedir.

Çalışmada yapılan regresyon analizi sonucunda da sosyal desteğe yönelik algının katılımcıların yaşam tatmin ve özgüven düzeylerini etkilediği görülmüştür. Sosyal destek algısının göçmenlerin yaşam kalitesini yükselttiği ve yaşamdan memnuniyet duymalarına katkı sağladığı sonucuna ulaşılmıştır. Sosyal desteğin bir anlamda katılımcıların zorlu ve olumsuz yaşam koşullarının sonuçlarını hafiflettiği söylenebilir. Göçmenlerin yaşam tatmin düzeyleri yükseltilmek istendiğinde onlara sağlanan sosyal desteğin artırılması yoluna başvurulabilir.

Araştırma sonucunda elde edilen bir diğer bulgu, algılanan sosyal desteğin yaşam tatminine oranla en çok özgüveni etkilediği şeklindedir. Elde edilen bu sonuca göre katılımcıların kendilerini rahat bir şekilde ifade etmelerinde, başkalarıyla kolaylıkla iletişime geçmelerinde, yeni girdikleri ortamlara uyum sağlamalarında ailelerinden, arkadaşlarından ve hayatlarındaki özel kişilerden gördükleri olumlu desteklerin oldukça fayda sağladığı ifade edilebilir. 


\title{
EXTENDED ABSTRACT
}

\section{The Relationship Between Perceived Social Sup- port, Life Satisfaction And Self-Confidence: A Rese- arch On Immigrants}

\author{
İnci Fatma Doğan
}

Kahramanmaraş Sütçü Imam University

The phenomenon of migration, which should be dealt with multidimensional in terms of its causes and consequences, constitutes an inevitable social problem (Koçak and Gündüz, 2016, p.67). Various factors such as higher income level, better living conditions, better education, a safer environment, economic, social, cultural and political factors cause migration movements and the continuation of this migration continuously (Akhan and Batmaz, 2015, p.24). It is a difficult process that migrants adapt to new settlements as a result of migrations that have forced people to leave places where they live for various reasons. People settling in a different country where they do not feel themselves, can cause emotions such as loneliness, exclusion, burnout and reduce life satisfaction (Adigüzel, 2016, p.173). New life, new conditions, external demands and pressures that meet people who migrate as much as their biological and psychological needs make their adaptation processes difficult (Silverman, 1987). If people cannot find enough power to adapt to the changes they face and deal with the challenges they face, this can lead to various physical, psychological and behavioral consequences (Lahey, 2004; Agoha vd., 2015, p.2728). However, it is stated that people who have social support from family, relatives, friends or other people around them can overcome the troubled process more easily (Gün and Bayraktar, 2008, p.168). It is thought that the social support of the immigrants plays an important role in the adoption by the society they are migrating, finding a job and being able to be economically safe, meeting their needs, and at establishing good and satisfactory social relations with the people around them. 
In general, the perception of social support is the cognitive evaluation that a person is supported by important social network members such as family and friends (Toepfer, 2010, p.57). Social support roles may be instrumental (tangible aids and services), emotional (empathy, love, trust and caring), informational (advice and suggestions), or appraisal support (affirmation and feedback) (House, 1981), any of which may be actually present or perceived to be present (Demaray and Malecki, 2002; Agoha et all, 2015, p.28).

Life satisfaction is a general affective and reflective attitude towards life (Kasprzak, 2010, pp. 144). It is the case that individuals compare their own conditions with the appropriate standards they consider to be (Diener vd., 1985, p.71). Maltby et al (2004) found that people who have more life satisfaction, use more effective and more appropriate coping styles, experience more deeper positive emotions and have more public health. Lack of life satisfaction is associated with poorer health status, symptoms of depression, inappropriate healthy behavior and social status (Tamannaeifar and Behzadmoghaddam, 2016, p.8).

Self-confidence is extremely important in almost every aspect of our lives (Janagan and Wahab, 2010, pp.11). Self-confidence is "an asset which makes people sit up and notice you, respect you and estimate you to be a potential confidant/ally/opponent" (Gandhi, 2010, p.8). Self-efficacy and self-esteem contribute to self-confidence.

In the literature, there are studies examining the relationship between social support, which is considered as one of the factors that have an important effect on life satisfaction and life satisfaction levels of individuals (Akın, 2008; Boylu ve Günay, 2018; Hamaideh vd., 2014; Kasprzak, 2010; Özdevecioğlu, 2004; Polatc1, 2015; Tamannaeifar ve Behzadmoghaddam, 2016; Topkaya ve Kavas, 2015; Zhou ve Lin, 2016). Mcknight et al. (2002, p.679) also stated that social support is one of the strongest predictors of life satisfaction of adolescents. Again, it is known that social support also has positive effects on the self-confidence of individuals (Rees and Freeman, 2007; Süpçeler, 2016). However, as a result of the literature review, we did not find any study investigating the relationship between social support and life satisfaction or self-confidence with social support. When the studies on migrants were examined, it was noted that the issue of social support was separately addressed (Çetin, 2009; Yaşar et al., 2014) and 
the issue of life satisfaction was addressed separately (Akhan and Batmaz, 2015; Calvo et al., 2017; Gunasekara et al., 2014; Kim, 2000; Şeker and Sirkeci, 2014; Vohra and Adair, 2000). In this context, it was aimed to examine whether the perceived social support of migrants has an impact on life satisfaction and self-confidence levels. It was hypothesized that significant relationships would be found between perceived social support, life satisfaction and self-confidence of migrants.

When the relationships between the variables are examined; it was determined that there was a statistically significant relationship between the social support perception of the participants and their life satisfaction and self-confidence levels. In particular, the relationship between perceived social support and self-confidence was higher than that of life satisfaction. In terms of perceived social support dimensions, it was noted that the relationship between support that perceived from someone special and selfconfidence was stronger than other variables. As a result of the regression analysis conducted in the study, it was observed that the perception of social support influenced the life satisfaction and self-confidence levels of the participants. It was concluded that the perception of social support increased the quality of life of migrants and contributed to their satisfaction with life.

\section{Kaynakça / References}

Adıgüzel, Y. (2016). Göçmenlerin kültürel entegrasyonu. A.Esen ve M.Duman (edit.), Türkiye'de Geçici Koruma Altındaki Suriyeliler:Tespitler ve Öneriler, İstanbul: Aryan Basım.

Agoha, B.C.E., Ogwa, F., Evbuoma, K., Igbokwe, D. ve Idoko, J. (2015). Perceived social support, perceived stress as correlates of stress symptomatolog among university students. Covenant International Journal of Psychology (CIJP). Maiden Edition, 1(1), 27-34.

Akhan, L.U. ve Batmaz, M. (2015). Bulgaristan'dan Türkiye'ye gelen göçmenlerin yaşam profillerinin memnuniyet durumlarına etkisi. $\mathrm{Bi}$ lig, 75, 23-42.

Akın, A. (2007). Öz-güven ölçeği'nin geliştirilmesi ve psikometrik özellikleri. Abant İzzet Baysal Üniversitesi Ĕ̆itim Fakültesi Dergisi, 7(2), 167176. 
Akın, M. (2008). Örgütsel destek, sosyal destek ve iş/aile çatışmalarının yaşam tatmini üzerindeki etkileri, Erciyes Üniversitesi Sosyal Bilimler Enstitüsü Dergisi, 25(2), 141-170.

Boylu, A.A. ve Günay, G. (2018). Yaşlı bireylerde algılanan sosyal desteğin yaşam doyumu üzerine etkisi, İnsan ve Toplum Bilimleri Araştırmaları Dergisi, 7(2), 1351-1363.

Calvo R., Carr D.C. ve Matz-Costa C. (2017). Expanding the happiness paradox: Ethnoracial disparities in life satisfaction among older $1 \mathrm{~m}-$ migrants in the United States. Journal of Aging and Health, 29(1), 125.

Cutrona, C.E., Cole, V., Colangelo, N., Assouline, S. G. ve Russel, D. W. (1994). Perceived parental social support and academic achievement: An attachment theory perspective. Journal of Personality and Social Psychology, 66(2), 369-378.

Çetin, H. ve Uysal, A. (2013). Bulgaristan Göçmeni Yaşlılarda Sosyal Ağ ve Sosyal Destek, Turkish Journal of Geriatrics, 16(2), 192-201.

Diener, E., Emmons, R.A., Larsen, R.J. ve Griffin, S.. (1985). The Satisfaction with life scale. Journal of Personality Assessement, 49 (1), 71-75.

Gandhi, S. (2010). Self-confidence - an asset to all humans, Journal of School Social Work, 6(2), 8-10.

Gunasekara A., Rajendran D. ve Grant S.. (2014). Life Satisfaction of Sri Lankan and Indian skilled migrants in Australia. Asian and Pacific Migration Journal, 23(4), 475-499.

Gün, Z. ve Bayraktar, F. (2008). Türkiye'de iç göçün ergenlerin uyumundaki rolü. Türk Psikiyatri Dergisi, 19(2), 167-176.

Hamaideh S, Al-Magaireh D, Abu-Farsakh B. ve Al-Omari H. (2014). Quality of life, social support, and severity of psychiatric symptoms in Jordanian patients with schizophrenia. J Psychiatr Ment Health Nurs. 21(5), 455-65.

House, J.S. (1981). Work stress and social support. Reading.Mass: AddisonWesley.

Janagan, E. ve Wahab, H.A. (2010). Improving positive self-confidence. Journal of School Social Work, 6(2), 11-13.

Kapteyn, A., Smith, J.P. ve Soest, A.V. (2009). Comparing life satisfaction. RAND Labor and Population Working Paper Series. 
Karakuş, S. ve Ünsal, S. (2017). Özel eğitim öğretmenlerinin psikolojik dayanıklılık ile mesleki sosyal destek düzeyleri arasındaki ilişkinin incelenmesi, International Journal Of Eurasia Social Sciences, 8(29), 831-850.

Kasprzak, E. (2010). Perceived social support and life-satisfaction, Polish Psychological Bulletin, 41(4), 144-154.

Kim M.S.. (2000). Life satisfaction, acculturation, and leisure participation among older urban Korean Immigrants. World Leisure Journal, 42(2), $28-40$.

Koçak, O. ve Gündüz, R.D. (2016). Avrupa Birliği göç politikaları ve göçmenlerin sosyal olarak içerilmelerine etkisi. Yalova Sosyal Bilimler Dergisi, 6(12), 66-91.

Lahey, B. (2004). Psychology: An introduction (8th ed.) New York: McGrawHill.

Lapa T.Y., Ağyar, E. ve Bahadır, Z. (2012). Yaşam tatmini, serbest zaman motivasyonu, serbest zaman katılımı: Beden eğitimi ve spor öğretmenleri üzerine bir inceleme:Kayseri İli Örneği. SPORMETRE Beden Eğitimi ve Spor Bilimleri Dergisi, 10(2), 53-59.

McKnight, C.G., Huebner, E.S., ve Suldo, S.M. (2002). Relationships among stressful life events, temperament, problem behavior, and global life satisfaction in adolescents. Psychology in the Schools, 39, 677-687.

Özdamar, K. (1999). Paket programlar ile istatistiksel veri analizi. Eskişehir:Kaan Kitabevi,

Özdemir, N.K. (2016). Deneysel bir çalışma: Bibliyopsikolojik danışmaya dayalı özgüven geliştirme programının 6. sınıf öğrencilerinin özgüven düzeylerine etkisi. Elementary Education Online, 15(1), 136147.

Özdevecioğlu, M. (2004). Sosyal destek ve yaşam tatminin mesleki stres üzerindeki etkileri: Kayseri'de faaliyet gösteren işletme sahipleri ile bir araştırma. H.Ü. İktisadi ve İdari Bilimler Fakültesi Dergisi, 22(1), 209-233.

Pearson, R.E. (1990). Counseling and social support:Perspectives and practice. Califomia: SAGE Publication, Inc. 
Polatc1, S. (2015). Örgütsel ve sosyal destek algılarının yaşam tatmini üzerindeki etkisi: İş ve evlilik tatmininin aracılık rolü, Ekonomik ve Sosyal Araştırmalar Dergisi, 11 (2), 25-44.

Proctor, C., Linley, P.A. ve Maltby, J. (2017). Life satisfaction, R.J.R. Levesque (eds.), Encyclopedia of Adolescence, pringer International Publishing AG 2017.

Rees, T. ve Freeman, P. (2007). The effects of perceived and received support on self-confidence, Journal of Sports Sciences, 25(9), 1057-1065.

Silverman, R. E. (1987). Psychology (3rd ed). New jersey: Prentice Hall Inc. Süpçeler, B. (2016). Ergenlik Döneminde Algılanan Sosyal Destek ile Yaşam Doyumu ve Özgüven İlişkisi. Yüksek Lisans Tezi, Yakın Doğu Üniversitesi, Eğitim Bilimleri Enstitüsü, Lefkoşa.

Şeker, B.D. ve Sirkeci, İ. (2014). Birleşik Krallık'daki Türkiye kökenli kadınlarda yaşam doyumu: Kimlik, kültürleşme ve ayrımcılık. Türk Psikoloji Yazıları, 17, 69-81.

Tamannaeifar, M.R. ve Behzadmoghaddam, R. (2016). Examination of the relationship between life satisfaction and perceived social support. International Academic Journal of Organizational Behavior and Human Resource Management, 3(3), 8-15.

Thomas, I. ve Raj, H. S.S. (1985). A factor analytical study on the antecedents of self-esteem. Psychological Studies, 1985, 30(2), 21-25.

Toepfer, S.M. (2010). Family social support and family intrusiveness in young adult women. Family Science Review, 15(2), 57-65.

Topkaya, N. ve Kavas, A.B. (2015). Algılanan sosyal destek, yaşam doyumu, psikolojik yardım almaya ilişkin tutum ve niyet arasındaki ilişkiler: Bir model çalışması, Turkish Studies International Periodical For The Languages. Literature and History of Turkish or Turkic, 10(2), 979-996.

Vohra N. ve Adair J.. (2000). Life satisfaction of Indian immigrants in Canada. Psychology and Developing Societies, 12(2), 109-138.

Yaşar, M. (2014). İstatistiğe yönelik tutum ölçeği: Geçerlilik ve güvenirlik çalışması. Pamukkale Üniversitesi Eğitim Fakültesi Dergisi, 2(36), 5975 . 
Yaşar, M.C., Kızıltepe, G.İ., Uyanık, Ö., Özsüer, S., Kandır, A. ve Aslan, V. (2014). Afyonkarahisar ilinde zorunlu ikamet eden sığınmacı kadınların sosyal destek algılarının incelenmesi. Sosyal Politika Çalışmaları Dergisi, 14(33), 9-27.

Yıldırım, İ. (1997). Algılanan sosyal destek ölçeğinin geliştirilmesi güvenirliği ve geçerliği. Hacettepe Üniversitesi Ĕ̆itim Fakültesi Dergisi, 13, 81-87.

Zimet, G.D., Dahlem, N.W., Zimet, S.G. ve Farley, G.K. (1988). The multidimensional scale of perceived social support. Journal of Personality Assessment, 52, 30-41.

\section{Kaynakça Bilgisi / Citation Information}

Doğan, İ. F. (2019). Algılanan sosyal destek ile yaşam tatmini ve özgüven ilişkisi: göçmenler üzerinde bir araştırma.OPUS-Uluslararası Toplum Araştırmaları Dergisi, 12(18. UİK Özel Sayıs1), 586-606. DOI: 10.26466/opus.585405 